\title{
Culture and Piety in the Far West: Revival in Penzance, Newlyn and Mousehole in 1849
}

A brief but classic account of a Cornish revival is to be found in Salome Hocking's book Some Old Cornish Folk, published in 1903. Writing semi-fictionally but also semi-ethnographically about a number of years before, the author, herself sprung from Cornish Methodism, described the thronging penitents, the exuberant singing and the 'thrill of excitement' that went through the village. Crucially she commented on the circumstances. The revival, she explained, had arisen 'at a time when no one was thinking about it, and no special services were being held. It seemed to have nothing to do with the preacher either...'. The event, she was suggesting, was entirely spontaneous. Although it was triggered by a young girl going forward to kneel as a convert below the pulpit, the subsequent stir was not the result of any earlier contrivance. The awakening was unexpected, not planned. Much of the writing about revivals - periodic episodes of religious enthusiasm attended by mass conversions in evangelical Protestantism - revolves around this distinction. Nineteenth-century advocates of revivals, in America as well as in the British Isles, contrasted the older pattern in which 'Christians waited for them as men are wont to wait for showers of rain' with the later way in which the episodes were promoted by 'systematic efforts'. ${ }^{2}$ Subsequently historians have taken up the theme. John Kent, the leading commentator on English revivals of the Victorian era, while recognising the existence of planning among some early nineteenth-century Methodists, places the dividing line between the prevalence of contagious spontaneity and the use of devices to achieve conversions after 1860. The mass urban evangelism of Dwight L. Moody and Ira D. Sankey in the 1870 s was clearly of a different kind, pointing towards the 
methods of Billy Graham in the twentieth century, from the artless techniques of John

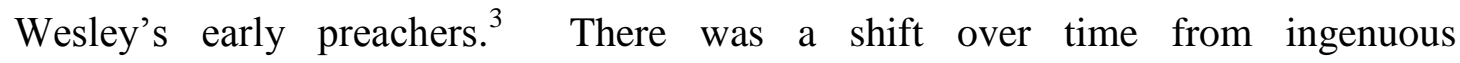
unsophistication to deliberate professionalism.

The nature of the transition, however, is much less clearly illuminated in the secondary literature than might be hoped. What actually happened in revivals has been very little studied. All too often accounts of revivalism have tended towards the general. There has been a natural concern among those sympathetic to the practice of revival to stress the widespread extent of the phenomenon, often leading them to assemble a great deal of disparate material and not to make distinctions between different patterns of awakening. ${ }^{4}$ Historians have usually been most interested in the causes of revival, often wanting to engage with the theories of E. P. Thompson about the relation of religious excitement to radical mobilisation or the common view that awakenings have been symptoms of community dislocation or economic recession. In establishing (as it has been fairly firmly established) that no constant correlations exist between such political, social or economic factors and the emergence of revivals, commentators have necessarily looked for the common features of a large number of awakenings, whether at different times or in different places. Their work has aimed to generalise rather than to particularise. Yet it is only accounts of specific revivals that enable us to understand their ethos, and especially the balance between the unplanned and the contrived. The potential of a particularising method is illustrated in a recent study by Ken Jeffrey of the 1858-62 revival in the north-east of Scotland, which shows that different styles with contrasting degrees of planning were proceeding in parallel in city, countryside and coastal settlements. ${ }^{5}$ It is true that the question of typicality arises for any local study, but it is only the multiplication of 
careful dissections of individual revivals that will resolve the issue of how representative any given episode may be. Far more work of a detailed kind on specific places needs to be done. We need to move from the general to the particular.

That step entails a thorough study of the internal dynamic and the external setting of the churches concerned in revival. On the one hand, the state of devotional life, all too often ignored in general accounts, calls for examination. It was the religiosity of the people that, when quickened, gave rise to revival. On the other, the whole surrounding ambience of the churches requires scrutiny. The place of those active in revival, whether as promoters or as converts, has to be understood in all the circumstantial detail of its communal context. We certainly need to know about the preconditions of revival that earlier accounts have usually taken as their central topic, but particular attention also ought to be paid to spirituality and to the total way of life of the area. That is what is attempted here. If older work took 'religion and society' as its rubric, this case-study takes 'piety and culture' as its major themes. It explores a Cornish Methodist subject. In England Methodists formed the most revivalist denominational grouping, and they were at their strongest in Cornwall. David Luker has already written a doctoral thesis on Methodism in Cornwall and has published an article on revival there. His conclusion is that we need to discover far more about internal developments and adherents' aims than has previously been customary. ${ }^{6}$ This paper seeks to achieve that goal. By drawing on the copious Methodist circuit records as well as the census, the Cornish press and other local sources, it aims to present a picture of revival in the far west that gives due weight to the whole cultural setting and the piety at the heart of the movement. ${ }^{7}$ 
We need to begin by setting the scene. In the mid-nineteenth century Cornwall, a county extending far into the Atlantic, retained a certain seclusion. The Tamar bridge connecting the Cornish railways with the national system was not to be opened until 1859, and even then Penzance, the westernmost town in England only eight miles short of Land's End, was fully 325 miles away from London. In 1849 the normal route to the capital was by coach to the north coast of the county, by boat up the Bristol Channel and by coach again from Bristol to London. The area round Penzance contained some good arable land, but far more significant was the mining of copper and tin in its hinterland. Copper extraction had boomed during the early nineteenth century and was to reach its peak in the 1850s; tin, which had long been a staple Cornish product, was to outlast copper. Miners lived near Penzance, though few had homes in it, and a good deal of the metal was exported through its harbour. Shipping, which increased by $30-40 \%$ over the decade down to 1848 , was the foundation of the town's wealth. ${ }^{8}$ Penzance was also taking the first steps towards exploiting its mild climate to attract tourists for their health. Following a much publicised visit in 1846 by Victoria and Albert to St Michael's Mount in the bay, the town advertised itself as 'the Montpellier of England'. ' So Penzance was a commercial rather than an industrial centre, and, notwithstanding its undoubted remoteness, even added a touch of the urbane to the urban. By the time of the revival it contained a population of some $9,200 .^{10}$

The other two foci of revival, Newlyn and Mousehole, also gained their living from the sea, but more directly, by fishing. Newlyn, lying a mile south of Penzance, was the chief fishing station on Mount's Bay. Possessing a population of about 2,100, less than a quarter the size of Penzance, it consisted of two settlements, accessible to 
each other only when the tide was right. The inhabitants of Newlyn Town were nearly all fisherfolk; the people of Street-an-Nowan, where the Wesleyan Methodist chapel stood, and the adjacent Tolcarne were more varied, for there was a large brewery, together with several shops and workshops, and the urban influences of Penzance were closer by. Nevertheless the roughly three hundred boats were the mainstay of the place, taking more pilchards and mackerel than anywhere else in Cornwall. $^{11}$ The scarlet-coated fishwives were a local sight, and by the 1880 s the artists of the Newlyn school of were to delight in depicting the rude simplicity of their menfolk. The artists used to complain, however, that their subjects insisted on whiling away the long sittings by singing tuneless hymns. ${ }^{12}$ Mousehole, three miles south of Penzance and round a projection in the cliffs from Newlyn, was even more single-mindedly devoted to fishing. Once a market town, it had never fully recovered from a burning by the Spaniards in 1595 in retaliation for the defeat of the Armada. It seemed a repository of the region's past, being the home of the reputed last speaker of the Cornish language, Dolly Pentreath, who had died in 1777 . Older people at the time of the revival had known Methodists who had once been smugglers. ${ }^{13}$ Mousehole was roughly half the size of Newlyn, with about 1,100 people and eighty boats. ${ }^{14}$ Maritime experience formed the outlook of the inhabitants, so that the leading Mousehole class leader in the revival could remark on his deathbed in 1870 that, despite acute physical pain, he was 'quiet on a calm sea'. ${ }^{15}$

The ecclesiastical balance in Penzance differed sharply from that in the fishing villages. The Church of England was reasonably strong in the town, which fell within the historic parish of Madron. The parish church was a mile and a half away, so that Penzance itself was served by a chapel of ease, St Mary's, which was rebuilt on a 
commodious scale in 1832-35. An additional Anglican place of worship, St Paul's, was opened in 1843. The relative resources of church and chapel can be illustrated from donations for the support of the town's day schools in 1849: whereas $£ 14$ was raised for the Wesleyan institution, $£ 44$ was collected for the National School of the Church of England. ${ }^{16}$ In terms of worshippers, the honours were more even. At the 1851 religious census, when the Wesleyans obtained $29 \%$ of the attendances in the town, the Church of England secured 43\%. ${ }^{17}$ In Newlyn and Mousehole, by contrast, it was Methodism that dominated. In both places, the second best attended place of worship was a type of Methodist chapel, Primitive in Newlyn and Teetotal in Mousehole, while the Church of England still suffered from memories of the fish tithe imposed until as recently as the 1830 s. ${ }^{18}$ The parish church that in theory served the two villages was up the hill behind Mousehole at Paul, a hamlet named after the church's dedication, and few of the fishing population darkened its doors except for funerals. At the 1851 census, perhaps prudently, it made no return of attendances. The Wesleyans claimed as many as $60 \%$ of worshippers in Mousehole. In Newlyn in February 1849, while the revival was flaming, a renovated ex-Methodist chapel was opened as the first Anglican place of worship in the village. ${ }^{19}$ At the religious census, however, when the Wesleyans attracted $40 \%$ of the worshippers, it drew a mere $13 \%$. Penzance was still a place where the established church enjoyed cachet, but in the fishing villages it had been practically disestablished by popular choice.

It will be useful to set out the events of the awakening before proceeding to analyse them. The first happenings were in Penzance. Around Christmas 1848 one or two young people professed conversion, and very rapidly a movement developed among the youth of the Wesleyan chapel. ${ }^{20}$ Whereas normally only five or so new 
members were admitted on trial each quarter, in the three months down to the end of the year as many as 46 were received. ${ }^{21}$ In Mousehole there was a conversion at the late evening watchnight service on New Year's Eve, and at a Sunday school teachers' meeting the following day two people revealed themselves to be 'penitents', that is convinced of their sinful state and active in seeking salvation. During a short period of about ten days many others in the village joined them in their earnest quest. At that point the fishing boats departed for the mackerel fishery off Plymouth, but the revival continued among the inhabitants who were left behind. Meanwhile the first signs of an awakening were seen at Newlyn on Sunday 14 January, when the boats were already setting off, and gradually built up to an even greater intensity than in Mousehole. Before the end of March the fishermen were back and participated fully in the stirring times. During the first quarter of the year there were 187 admissions of new members on trial at Penzance, 240 at Mousehole and as many as 266 at Newlyn. On a single day, Easter Monday, 9 April, at a series of special services in Newlyn, about one hundred people professed conversion. In March and again in June there was a torrent of public testimony to changed lives at the love-feasts observed in Penzance and at similar gatherings held in the fishing villages. Fresh admissions on trial in the quarter ending in June were 64 for Penzance, 48 for Mousehole and 105 for Newlyn. Then, however, the boats set off for the Irish fishing grounds and the revival tailed off, with 35,15 and 33 new admissions in the third quarter and normal figures in the last quarter. Overall the total membership of the Penzance circuit rose in twelve months by no less than $70 \%$. It was a transformative experience for the district. 
Preceding events undoubtedly had a bearing on the awakening and it is worth considering, in the first place, how far economic circumstances impinged on its genesis. The 1848 fishing season had been poor. In August 1848 it was noted disconsolately that the pilchards had disobligingly swum off into deep water or else to the vicinity of Land's End. ${ }^{22}$ Unless 'some peculiar good fortune' should transpire, reported the Penzance Gazette in December that year, 'we shall have to record one of the most discouraging seasons which has been experienced in this bay. ${ }^{23}$ The fishing population depended exclusively on their catches, and so the prospect of a hard winter may have contributed to rousing minds to eternal things. Yet the start of the 1849 fisheries was much more satisfactory. By February the Penzance fish market was being abundantly supplied with turbot, brill, salmon, eel, cod, ling and sole. Newlyn boats were taking large quantities of mackerel off Plymouth and finding good prices for their catches. ${ }^{24}$ Although the summer expedition to Irish waters was 'very unsuccessful' that year and local landings much below average, so that by the autumn there was 'abject poverty' in Newlyn and Penzance, ${ }^{25}$ at the height of the revival the chief source of income of the fishing villages had been flourishing. It is just possible that gratitude to the Almighty for renewed prosperity after a meagre season encouraged religious enthusiasm, but direct evidence is lacking. In any case, it is implausible in this instance to connect the awakening with poor economic circumstances.

A definite link, however, can be made with a very different factor, alarm about cholera. In 1832, when the last outbreak had taken place in Britain, the Methodist superintendent in Penzance had attributed a revival of that year in part to "pestilential diseases'. ${ }^{26}$ The knowledge that life might suddenly be cut short had turned thoughts 
towards seeking salvation. The town of Penzance had experienced the epidemic, especially in the confined courts near the quay, with 64 deaths in a period of three months, and Newlyn had suffered even worse, with perhaps as many as a hundred fatalities. ${ }^{27}$ From August 1848 there were fears of a recurrence. Diarrhoea and dysentery, often the precursors of cholera, increased in Penzance. ${ }^{28}$ The people of the town read anxiously in their newspapers of the inexorable westward advance of the scourge over Europe: from St Petersburg to Berlin, to other towns in Germany and eventually to a Prussian vessel in the port of Hull. ${ }^{29}$ By mid-October there were fatal cases elsewhere on the east coast, and in the following month a Penzance sailor died of cholera on board one of the port's own schooners quarantined at Ramsgate. ${ }^{30}$ It was reported that "the public are anxiously enquiring "What is to be done?". 31 The Penzance health committee passed resolutions and the council resolved to initiate steps for the creation of a local board of health. ${ }^{32}$ The process reached a peak of activity in January, the very month when the revival took off. The Board of Guardians decreed fresh sanitary measures; a government inspector held a two-day hearing on 10 and 11 January to establish the need for a board of health; and the press, in urging 'every proper precaution', deprecated the 'foolish apprehensions' that were abroad. ${ }^{33}$ The popular worries were undoubtedly related to questions of faith. Even the Penzance Gazette hoped that the planning would, 'under Providence', avert an outbreak. $^{34}$ The expectation around the beginning of 1849 , though, was that the epidemic would soon strike the area. Twelve months later the senior Wesleyan minister was able to voice the relief of his people at having 'entirely escaped the ravages of pestilence'. ${ }^{35}$ For a while, however, fear of death encouraged fear of the Lord. 
Another type of awareness of mortality was often a powerful influence in places so dependent on the sea. There were deep-seated anxieties about the everpresent risk of death in the frail vessels. At night fishermen of the west of England avoided parts of the shore where there might have been wrecks in the past. Many of them claimed to have heard the voices of dead sailors calling to them. ${ }^{36}$ Most of the coastal folk had lost relatives or friends by shipwreck. In October 1848 a young Newlyn fisherman was lost at sea, but, because such events were so frequent, it does not seem to have had much impact. ${ }^{37}$ In December, however, the weather turned stormy and a succession of gales battered the area. ${ }^{38}$ On Thursday $14^{\text {th }}$, a schooner in distress was seen in the natural amphitheatre of Mount's Bay. Crowds came out to watch as, in a strong wind and a heavy sea, the boat, the James Whearne of St Ives, tried to make towards Penzance, but then, on the opposite side of the bay, it suddenly capsized. The six men and a boy in the crew were all lost. ${ }^{39}$ The harrowing melodrama, an unusually public spectacle of death, took place shortly before the first stirrings of awakening in Penzance and must surely have played a part in turning thoughts to questions of eternity. On Saturday $23^{\text {rd }}$, with destructive gales still blowing, Welsh colliers and other vessels crowded into Penzance harbour, causing collisions and rumours of more serious disasters, and on Christmas Day itself two schooners left the port only to run ashore not far away, one losing a boy. ${ }^{40}$ The people of Penzance, who showed 'intense fear and sympathy' on such occasions, thronged to the harbour to witness the scene on Christmas Eve, and the events were sufficiently worrying to prompt the council to resolve to shoulder a heavy debt by extending the town pier. ${ }^{41}$ The terrifying weather and the loss of life will have reinforced the preoccupation with death arising from the progress of the cholera. 
If the community at large was moved to anxiety by these circumstances, the Methodists had their own internal reasons for looking for a religious awakening. It has come to be appreciated that in the nineteenth century there was often a rhythm of revival. Churches that had experienced an awakening would expect another to take place after a few years. The only consistent factor preceding revivals, according to Richard Carwardine, was a belief that they were desirable and must be repeated. ${ }^{42}$ Accordingly churches engaged in intense bouts of prayer for a fresh visitation by the Holy Spirit and confidently expected their prayers to be answered. The Methodists of south-west Cornwall had particular cause to follow this pattern. In 1814 their part of the county, together with the mining heartland, had been enflamed by the 'Great Revival'. It was described by a contemporary as a 'glorious work'; there were scenes of agony, with people 'on their knees for six, twelve, or twenty hours, without intermission, crying aloud for mercy'; and over 5,000 new members crowded into the movement. ${ }^{43}$ Another general awakening in the south-west of the county took place in 1831-32, and there were lesser episodes at Mousehole in 1818 and 1828, in all three places in 1838-39, in Penzance in 1841-42 and in Mousehole and Newlyn in 1844. ${ }^{44}$ There can be no doubt that supplication for revival became a deeply rooted feature of Methodist spirituality in the area. In Penzance, it was said after the 183132 revival, 'our friends unite in ardent and unceasing prayer for the continued prosperity of Zion'. ${ }^{45}$ Memories of the Great Revival in particular lingered as a paradigm for what Methodism should ideally be about. Robert Young, the superintendent minister during the 1849 awakening, had published a book on Wesleyan revivals, chiefly in England but also in other parts of the world, before he came to Cornwall. By far the longest account was of the revival in the county during $1814 .^{46}$ For pastor and for people recollections of the Great Revival served as a spur 
to seek another similar event. The expectation was so powerful as to verge on being self-fulfilling.

Another dimension of Methodist piety was a sublime confidence in the future. It was not just that members felt assured of going to heaven, for they also believed that the cause of Christ was destined, according to the promises of scripture, to triumph all over the earth. The whole world, declared Robert Young in a missionary sermon of 1846, 'shall become one vast and holy temple of spiritual worshippers'. 47 Contemporary events seemed to vindicate that standpoint, technically labelled postmillennialism. The European revolutions of 1848, Cornish Methodists were told by William Arthur, a connexional missionary secretary, in the following year, had ushered in a 'glorious dawning of the spread of liberty of conscience' which would lead to the triumph of the pure gospel on the continent. Accordingly they threw themselves into the enterprise of world missions, certain that they were participating in the purposes of the Almighty. The Cornish district missionary meetings shortly before Easter were for Methodists the high point of the church year, far surpassing Easter itself in significance. Every year the greatest luminaries of the Wesleyan pulpit were despatched to the county for a preaching jamboree. The main public meeting of 1849 in Penzance, where Arthur spoke, was 'densely crowded' and the immense sum of $£ 171$ was raised over the anniversary weekend. ${ }^{48}$ Partly in consequence, the Wesleyan Methodist Missionary Society enjoyed enormous support in the area. A missionary auxiliary had existed at Mousehole from 1820, commissioning eighteen 'young females' to engage in competitive collecting for the global cause. ${ }^{49}$ Forty copies of the monthly Juvenile Missionary Offering circulated in the village in 1846, outdoing Newlyn's ten by a large margin. ${ }^{50}$ Joseph Carne, a rich banker of Penzance, 
had a seat on the missionary society committee in London from 1836 to 1849 , and Robert Young had actually served as a missionary between 1820 and $1826 .{ }^{51}$ Penzance itself had sent Samuel Symons to the Gambia in 1842, though he had succumbed to yellow fever within two years. ${ }^{52}$ The Methodism of the area was a hotbed of missionary enthusiasm.

The spiritual confidence associated with the missionary project had its repercussions for revival. Conversion was at the centre of both. If the world was rapidly turning Christian, the chapel attenders of Cornwall were inspired to feel that they must follow. Symons had sent back a leather collecting bag made by the people of the Gambia to Jane Dennis, a missionary zealot in Penzance. Jane was an invalid, confined to her bed by a spinal problem, but held regular prayer meetings in her room during which, according to a later memory, she would 'often be in an ecstasy'. Each year the visiting dignitaries for the missionary anniversary filed into her room so that they could receive the contents of her collecting bag. The room was also the place where many conversions took place under Jane's tutelage. ${ }^{53}$ Jane Dennis symbolised what contemporaries called the 'reflex action' of missions. Those who supported evangelistic effort overseas were constantly reminded of the duty to sacrifice ease and of the imperative to pray for conversions. This formula prepared the way for revivals in the locality. The chairman at a meeting of the Penzance Juvenile Wesleyan Missionary Society in November 1848 was Edward Rowe, a printer and bookseller, several of whose own children were to be converted in the revival that began the following month. ${ }^{54}$ The missionary atmosphere of the household must have affected its young people. Again, the revival in Mousehole actually started immediately after missionary speakers had addressed a meeting there. ${ }^{55}$ Following the revival, some of 
the young women who had professed faith for the first time discarded the artificial flowers that, as their minister severely remarked, had 'done questionable service in days of folly', and turned them into decorations for a work basket in which they placed articles for sale in support of overseas missions. Young converts of both sexes gave $£ 10$ as a thankoffering to the missionary cause. ${ }^{56}$ Even more strikingly, three of the young Mousehole converts volunteered in the following year to act as boatmen on a quixotic missionary venture to the southern tip of Patagonia. All the party perished, but the publicity given to these 'martyrs of the south' led to some of the first sustained efforts to plant Protestantism in South America. ${ }^{57}$ The revival was to contribute to the missionary cause, but the converse was also true. Devotion to the missionary enterprise had helped prepare the churches for revival.

These various antecedent factors meant that, even if the awakening of 1849 showed certain characteristics of spontaneity, there were influences at work among the Methodists of the Penzance district that predisposed them to revival. Furthermore, there are reasons for seeing the events of that year as the result of conscious planning. The ministers in the circuit had been appointed to produce organised revivals. The attitude of the pre-eminent figure in Wesleyan Methodism in these years, Jabez Bunting, has sometimes been misinterpreted as involving hostility to revival for the sake of orderly control, but in reality he believed in encouraging awakenings so long as they did not disrupt regular circuit life. 'We may excel in getting revivals', he told the 1837 Conference, 'but we have yet to learn how to manage them.' 58 His ideal, then, was managed awakenings. Leading laymen in Cornwall, sharing his opinion, were troubled that Methodism in the county, though full of vitality, needed better organisation, not least to ensure connexional loyalty. ${ }^{59}$ George Smith of Camborne 
urged the authorities to appoint gifted ministers to the Cornwall district. 'It is not rant, nor senseless declamation, nor a profusion of terrific epithets, which is likely to produce a revival', he wrote a few years later, '... but plain earnest, forceful utterance of sterling Gospel truth'. ${ }^{60}$ Accordingly in 1846 two ministers were selected for the task of blending more discipline into the enthusiastic ways of the Cornish. ${ }^{61}$ Stationed at Truro for three years, in 1848 they moved to Penzance and so presided over the revival in the circuit there. The junior minister was John H. James, one of the first products of the Theological Institution that Bunting had established in 1836 to train able exponents of denominational principles. James had married the daughter of William Dale, the most prominent Truro layman, and already by 1839 had been seconding his father-in-law's calls for efficient ministerial leadership in Cornwall. ${ }^{62}$ He fulfilled his early promise, going on to become secretary (1870) and president (1871) of Conference, and was celebrated on his death for having combined 'culture and the revivalistic forte ${ }^{63}$ James was placed in Cornwall to be an exponent of directed revivals.

So was his superintendent minister, who also acted as chairman of the whole Cornwall district, Robert Young. Possessing rich missionary experience from Jamaica and Nova Scotia, at the time of the revival Young was in his early fifties and still a man of great energy. He showed a certain sternness, condemning ministers who excited 'the spirit of levity by pitiful witticisms or ludicrous anecdotes'. ${ }^{64}$ Yet he was himself a ready raconteur, enjoyed playing with his children and attracted deep affection as well as great respect from his flock. ${ }^{65}$ He was strongly in favour of revivals, composing in 1844 the standard Wesleyan handbook on the subject, Showers of Blessing. He approved of the Cornish style of intense revivalism, exhibiting the 
Penzance circuit as a good example of a place where awakenings had generated solid church growth. Nevertheless he upheld the official Wesleyan view, as codified in the minutes of the Liverpool Conference of 1820, that revival was best pursued by regular church work rather than by artificial stimuli. ${ }^{66}$ His zeal, according to his official obituarist, was tempered by 'sound judgment and unusual self-control'.67 The Wesleyan authorities twice entrusted him with responsibility for delicate negotiations in other parts of the world: in 1843-44 he travelled round the West Indies to resolve differences of opinion that had arisen among the missionaries; and in 1852-54 he was despatched to Australia to tell the Wesleyans that they must become independent and self-supporting, so that they would have to pay for the South Seas missions themselves. ${ }^{68}$ Young possessed the supreme diplomatic skill of presenting unwelcome news in a favourable light, and it is not surprising that on his successful return from Australia he was rewarded with the presidency of Conference in 1856. Similarly in the Penzance circuit Young headed off the Wesleyan reform movement that elsewhere, even in Cornwall, caused immense disruption during 1850-51. ${ }^{69}$ Robert Young was therefore particularly gifted to turn Cornish revivalism into more disciplined channels.

Young had a penchant for projects. His most ambitious, published in 1841, was a plan for nothing less than the conversion of the whole world. This goal could be achieved, he argued, if each converted person brought one soul to God every year. He calculated that, if the scheme were adopted by only 3,000 people at the start, within twenty years the entire population of the globe would be Evangelical Christians. To help the enterprise along, it would be useful to raise $£ 5$ millions for the support of 20,000 missionaries, which could easily be achieved if, in order to 
contribute to the cause, only a quarter of real Christians gave up half a pint of malt liquor per day. ${ }^{70}$ It is not surprising that, immediately after arriving as superintendent minister in Penzance in August 1848, he launched several schemes. The Sunday school staff were gathered for tea and, under Young's guidance, passed resolutions designed to increase their efficiency. ${ }^{71}$ The superintendent had the local preachers' meeting arrange to reopen St Clare Street Chapel, where there had previously been fitful efforts to start a second Wesleyan cause in the town. A committee under the leadership of a retired minister in the congregation, John Reynolds, was entrusted with visiting the neighbourhood to drum in new attenders. ${ }^{72}$ And at the September quarterly meeting, Young summoned the lay leaders in the circuit, as he later put it, 'to anticipate and labour for a revival of religion'. ${ }^{73}$ The scene was deliberately set for the awakening that duly followed.

During its course, Young controlled events with a firm hand. There is no detailed account of his procedure at Penzance, but he had described his customary approach in Showers of Blessing and, since we know that he followed its prescriptions in a revival at Truro in 1847 , he will also have followed the same pattern two years later. One regular bane of revival services was the arrival of young men bent on organising practical jokes. Accordingly Young stationed stewards at the doors to check what he called 'the ungodly and profane' ${ }^{74}$ A problem arising from undue ardour was a willingness to carry on until late hours that aroused criticism among outsiders. In the awakening of 1832 Penzance had kept a meeting going until eleven o'clock and Mousehole had continued until nearly midnight for a whole week. ${ }^{75}$ At Truro in 1847 , by contrast, Young insisted on closing by ten o'clock. There was resistance among those wedded to traditional ways, but the superintendent overbore 
them. ${ }^{76}$ Young's key policy, however, was what he called the separation of penitents. Those anxious for salvation were invited forward to the communion rail to receive spiritual advice. This method, professedly pragmatic in motivation, was designed to allow those concerned about their sins to take a decisive action. It also meant that busy-bodies no longer had an excuse for wandering about the chapel to intrude their advice on the most exciting cases, so that often two or three were "shouting into the ears of a poor sinner in distress, and expressing themselves in different language, and with much incoherency'. ${ }^{77}$ Instead advice was given only by designated counsellors who would be able to adapt their guidance to each individual's circumstances. Young attempted the separation of penitents at Truro in 1846, but the congregation, unaccustomed to the new procedure, simply ignored him. By 1847, however, the strategy worked. ${ }^{78}$ It was part of what Young termed the proper 'management' of revivals. $^{79}$

At Penzance such methods successfully imposed a particular character on the awakening. On his arrival in the town, Young was dismayed to discover that the children of what he called 'old and respectable' Wesleyan families were 'addicted to levities', so giving signs of being unconverted. He and his colleague took pains to speak in public of the requirement of commitment and in private of the need for repentance. When the revival came, it was overwhelmingly among those between fourteen and twenty-five years of age. ${ }^{80}$ There is no record, in fact, of any convert over the age of twenty-five other than the thirty-year-old daughter of a former minister. ${ }^{81}$ Previous revivals, such as one at Mousehole in 1818, had also harvested chiefly the young, ${ }^{82}$ but in Penzance in 1849 the converts had further characteristics. The managed tone of the revival made it acceptable to 'intelligent and educated' 
young people. ${ }^{83}$ Both sexes were drawn in, so that fresh weekly classes were begun for boys as well as girls - though the change was most apparent among the girls, who 'discarded superfluous ornaments, and adopted a quiet and godly attire' ${ }^{84}$ Brothers and sisters were converted together or in rapid succession, so that solitary recruits from a family were a rarity. There was a pattern of household conversion. The early closing of the meetings was explicitly aimed to avoid disrupting family life and part of the purpose of the ban on strolling counsellors was to eliminate those who were 'little acquainted with the rules of polite society'. ${ }^{85}$ It is evident that the revival was deliberately moulded so as to cater for the prosperous families of the town with whom Young closely identified. His own older daughter Elizabeth afterwards married the eldest son of W. D. Matthews, a wealthy shipowner, the proprietor of the town's only dry dock and later three time mayor, the son almost certainly being a convert during the revival. ${ }^{86}$ Conversion was being treated as a natural step for junior members of prospering Wesleyan households, a rite of passage rather like confirmation. Recruitment was no longer expected to be from the unchurched community, but from names already associated with Methodism. Growth was becoming an internal phenomenon.

This diagnosis is confirmed by the arrangements made during the revival for the care of converts. Methodism allocated newcomers to classes, each meeting weekly under a leader, and the sources allow us to discover something of their character. Of the twenty-seven class leaders operating in Penzance at the peak of the revival in the first quarter of 1849 , only four received a lion's share of the recruits, altogether well over half those who professed conversion. Their classes admitted between nineteen and forty members on trial, whereas the next largest intake was only 
nine and several classes received no fresh members at all. ${ }^{87}$ All four of the big recruiters possessed special reasons for an interest in the young. One, the already mentioned W. D. Matthews, was a chapel steward with responsibility for the future welfare of the cause and was in addition the father of a family that was particularly affected by the awakening, almost certainly with five children converted. Matthews took as many as thirty-three into a single class, which must have made for lively meetings. The second class leader, Richard Barnes, was the proprietor of Regent House Academy, a private school in the town much patronised by Wesleyans, and so had a professional concern for children. ${ }^{88}$ The third, Richard George, received a high proportion of the first wave of converts around Christmas, and he remained a key figure in similar phases of religious excitement right down to 1863, regularly welcoming large numbers of new members into his class. George, who was married but childless at the age of forty-three, did business as a confectioner in the town centre. His shop was known for its excellent macaroons, and so must have been popular with the young people of the town. ${ }^{89}$ The last class leader attracting a significant number of new admissions was Richard Hosking, a master mason, then only twenty-seven himself and so having an immediate affinity with the young people. He soon became a local preacher and continued to gather large numbers of new members into class in subsequent years right down to a revival in $1872 .{ }^{90}$ While the classes led by others maintained a more even-paced pastoral role, the groups led by these few men were the cutting edge of Wesleyan mission. Evangelism was becoming the care of experts who took a particular interest in young people. George and Hosking in particular were men who concentrated on enlisting new recruits. A distinct category of soul-winners was emerging. 
In the more polished setting of Penzance, therefore, the restrained and orderly style of revival promoted by Robert Young was associated with internal growth, youthful converts and evangelistic specialists. The fishing villages of Mousehole and Newlyn, however, were very different places. The dwellings were small, cramped and crowded in a restricted area, throwing people together. The fishermen generally operated their boats on a system of shares, so that the boat-owner, the captain and the crewmen all took a proportion of the proceeds of the catch. ${ }^{91}$ The result was an egalitarian atmosphere and a strong sense of community. Nicknames were common, and at funerals all the inhabitants would turn out, taking turns to carry the corpse up the hill to the churchyard. ${ }^{92}$ In such settings traditional ways survived tenaciously. The fishermen were noted for their superstition. No pasties, saffron cakes or looking glasses were tolerated on board ship; women, rabbits and preachers must not be seen just before a voyage. ${ }^{93}$ Fairy folk were supposed to dwell in holes in the cliff, and offerings of fish for a deity named 'Bucca', perhaps a regional variant on 'Puck', were still being left on the beach within a decade or so of the revival. The people of Mousehole seem to have abandoned this custom earlier and so to have derided Newlyn folk as 'Buccas'.94 This measure of detachment from inherited practice in Mousehole may have been a result of a thirst for education connected with the greater strength of Methodism in the village. In 1818 Mousehole Wesleyans had begun a book club, circulating volumes bound in black oil-cloth and selling them off after a year. ${ }^{95}$ A Methodist day school was opened in Mousehole in the year before the revival, whereas Newlyn had to wait until 1859 for its equivalent. ${ }^{96}$ Yet superstition and Methodism were undoubtedly compatible in both villages. Belief in invisible wandering spirits, according to an unfriendly Anglican commentator, was actually encouraged by Methodist local preachers. ${ }^{97}$ It is known that after evening chapel, a 
Mousehole villager might resort to an old man's house for a charm to cure toothache. ${ }^{98}$ Traditional patterns of behaviour were more likely to endure in the small and tight-knit communities.

There was also a feature of Methodist belief that was stronger outside Penzance than within the town. That was the conviction that after the moment of conversion there was a further decisive crisis in the spiritual life, the entry on entire sanctification. A believer, John Wesley had taught, might progress to the point of receiving perfect love, a condition in which the desire to do wrong was eradicated from the soul. It was an experience often associated with intense spiritual awareness and a species of boisterous revivalism. All Methodists formally acknowledged the doctrine, but as the nineteenth century advanced fewer expected the experience. ${ }^{99}$ That was particularly true in more sophisticated environments such as Penzance. We know that in 1817 three entered perfect love in the town and many members of the circuit, some of whom may have been people of Penzance, were said to have obtained it in the aftermath of the revival of $1832 .{ }^{100}$ Thereafter, however, there is no evidence for the experience in the town. Young, as a loyal Wesleyan, taught entire sanctification, but was acutely aware that some hypocrites claimed it though showing 'unholy tempers' and did not dwell on the subject. ${ }^{101}$ While there is no indication of the doctrine at Newlyn, however, it was clearly widely credited at Mousehole. Richard Trewavas, a patriarch of the society there, and William Carvosso, a travelling evangelist based in the village, were its exponents in the first third of the century. ${ }^{102}$ Benedict Carvosso, William's brother and a Mousehole class leader, upheld perfect love down to his death in $1823 .{ }^{103}$ Benedict, in turn, was a profound influence over the formative years of Joseph Wright, a class leader and local preacher who in 1849 
was the leading figure among Mousehole Wesleyans. ${ }^{104}$ When several fishermen converted during the revival visited Young some time afterwards to thank him for his efforts among them, they 'bore testimony to the efficacy of His blood to cleanse from all sin'. ${ }^{105}$ In Mousehole the doctrine of entire sanctification evidently played its part in fostering a more intense form of revivalism than appeared in Penzance.

In both the fishing villages there are signs that there was a great deal of the raw excitement that was traditional in Cornish revivals. A Newlyn clergyman diagnosed them a little later as "a "survival" of Druidism...a return to that ecstatic worship of the heathen Celt which only ecclesiastical authority restrained during the past ages'. ${ }^{106}$ Although Young's account of the revival, the only one available, did not go into detail about its emotional content, it is clear from stray phrases in his description that the events were passionately felt. Some individuals were suddenly awakened in the open air, fell on their knees and 'cried aloud for mercy'; fishermen at sea could be 'in solitary agony all the night'; and, coming ashore, they would be embraced by 'tearful but joyful' wives. ${ }^{107}$ Sturdy seafarers 'sobbed aloud and tears streamed down their cheeks' as they recounted their conversions. ${ }^{108}$ Young was quite prepared to tolerate such emotional display. Having grown used to similar happenings in the West Indies, he was convinced that forms of expression varied according to temperament. ${ }^{109}$ He recognised that Cornish revivals had usually been noisy, exuberant affairs, and objected only to allowing singing and praying at the same time. ${ }^{110}$ He was too skilful a diplomat to attempt to impose the same order on the fishing villages that he demanded at Penzance. So intense did the Mousehole revival become that it led to a painful episode. Mary Wright, a widow of around sixty living in the village, attended a Wesleyan prayer meeting on Christmas Eve 1848, 
before the awakening had begun, and was terrified when her nephew, who was giving out a hymn, fell down as if dead. ${ }^{111}$ As the revival emerged, her thoughts turned to religion, she became alarmed about her spiritual state, and, instead of reaching a sense of forgiveness, she lapsed into 'a morbid state of the feelings'. One Saturday morning she rose early, went downstairs and calmly cut her own throat. The coroner's inquest brought in a verdict of temporary insanity. ${ }^{112}$ Perhaps surprisingly, the suicide was not seized on by opponents to condemn the revival. The consternation it created in the village may even have advanced the awakening. The episode is an extreme instance of the way in which events in the fishing villages broke through the restraints successfully introduced in the town.

The character of the awakening in the fishing villages was therefore very different. There was no special harvest among the young, for every age group was affected. Whereas at Penzance converts were rarely over twenty-five, and so usually unmarried, here there were plenty of younger men over twenty-one, married as well as single. There were also men of sixty-five and over, even into their eighties. ${ }^{113}$ Instead of age limiting the conversions, there was a remarkable division by gender. In Mousehole, and perhaps in Newlyn too, it was the custom for men and women to sit on opposite sides of the chapel. ${ }^{114}$ The separation at worship no doubt reflected patterns of sociability deriving from the specialisation of labour within a fishing economy, with men going to sea and women responsible for fish curing. The same social arrangement recurred in the revival. At Newlyn, where the Wesleyans were preponderantly female before the awakening, there was a gendered division between some of its settings. Women had a prominent place in cottage prayer meetings, but men held their own meetings for prayer in boats at sea. ${ }^{115}$ Young remarked on the 
frequency of men among the converts in both villages. There was a gathering in Newlyn where three or four elderly men wept together in distress; and on Easter Monday, the hundred converts in the village were chiefly men. At Mousehole there were alternate phases when the awakening was predominantly male or female. At first the men took the lead, but soon they had to go to sea and so there was a time when wives, daughters and sisters were the subjects of the revival. Then, when the boats returned, the men took over once more. ${ }^{116}$ In the aftermath of revival the two sexes paid separate and very gender-specific tributes to their minister: some of the men named one of the fishing boats the Robert Young while the women gave him a silver-plated teapot. ${ }^{117}$ By contrast with Penzance, where the revival reaffirmed the solidarity of the family, in the fishing villages it followed the traditional gender divisions of the settlements. Outreach was not just gathering the young of the congregation but was penetrating the area as a whole. In Mousehole and Newlyn revival was a community affair.

There was, however, a significant difference between Mousehole and Newlyn. Whereas in Mousehole the awakening soon faded away, in Newlyn it was more protracted. Although the number of new members was roughly equal in the two places during the first quarter of 1849 , there were more than twice as many in Newlyn as in Mousehole during the second and third quarters. ${ }^{118}$ The contrasting patterns of recruitment are explicable in terms of the role of the class leaders. In Mousehole many of the classes were naturally led by fishermen. One of the four leading recruiters at the peak of the revival, William Beadon, was a ship's captain. ${ }^{119}$ His new admissions fell from 31 in the first quarter to 2 and 1 in the next two periods. Likewise three other class leaders who can be identified as involved in fishing had 
only a single new recruit between them in the second and third quarters. ${ }^{120}$ Only one of the class leaders who was a fisherman, Joseph Wright, managed to keep up his work of adding new converts, and he was exceptionall in being the leading figure in the Methodist society. It seems clear that the community was incapable of sustaining revival for more than a few weeks when its keenest advocates were absent at sea. In Newlyn, by contrast, the nine class leaders were more varied in occupation: two had private means, three were grocers, one was an artisan, two cannot be firmly identified and only one was definitely a fisherman. ${ }^{121}$ These people were generally available to be called from their work to assist those seeking salvation. ${ }^{122}$ The one class leader who proved a relatively weak recruiter, with only 4 members on trial in the first quarter and only 2 in the next two quarters together, was a fisherman. The exception confirms the overall case: it was hard for a place like Mousehole, where community leaders were seafarers, to keep up a long revival, but it was much easier in Newlyn, where occupations were far more varied. The dynamic of the Wesleyan classes therefore reflected the specific circumstances of the two villages. It is clear that there was no planned or imposed uniformity. The revivals of Mousehole and Newlyn were faithful reproductions of the distinctive environment of each place.

In any overall view of the events of 1849 , however, the more marked contrast was between Penzance on the one hand and Mousehole and Newlyn on the other. The cultural difference is well illustrated by the circulation of the fairly weighty Wesleyan Methodist Magazine in the three places. Four years before the revival, when Penzance had eighteen subscribers, Mousehole had only four and Newlyn only a single one. ${ }^{123}$ Penzance, with its more sophisticated readers, was a natural scene for an organised, orderly revival run by selected specialists. The event drew in young 
people from the congregation, but few outsiders, so inaugurating an era when Methodism in the town recruited largely from its own ranks. ${ }^{124}$ Mousehole and Newlyn, with a less inhibited piety, experienced a more emotional awakening. Growth was still commonly from the outside, with the whole community stirred and a large number of older converts of both sexes. It was not long afterwards, however, before the changes already apparent in Penzance began to affect the fishing villages. In 1860, when revival again visited the villages, the chief class leaders taking in the converts were the Wesleyan day school teachers of the two places. ${ }^{125}$ Additions to the church were now expected to come from the children and were left to the professionals. By the 1890s Newlyn was holding a pre-planned mission with a paid district evangelist and Mousehole was conducting a revival, again organised in advance, complete with enquiry room and described as 'less loud and sensational than those of former times'. ${ }^{126}$ Even in these haunts of old-fashioned ways the transformation of the revival tradition was in the longer term irresistible.

The awakening of 1849 was therefore at a point along a continuum that extended from the spontaneous to the contrived. It turns out not to have been the result of some unpredictable religious impulse such as Salome Hocking envisaged. The fear of death, whether from cholera or drowning, was clearly at work, as were hopes of a revival and the example of foreign missions, preventing the event from being entirely unprompted even before any deliberate encouragement. The ministers, however, set out both to foster the revival spirit and to turn it into acceptable channels. They succeeded in generating a revival at Penzance that was suffused with respectability. In the fishing villages, however, they bowed to the exuberant manners of the more traditional communities. In what was apparently a single happening, 
there were strikingly different styles of revival proceeding simultaneously, with even Newlyn and Mousehole revealing some contrasts. The microcosm of these places in south-west Cornwall reveals something of what was really happening in awakenings as culture and piety interwove. The microcosm, furthermore, sheds light on the macrocosm of the chronology of revival. There was evidently a shift over time from an earlier freedom of expression to a later imposition of decorum, from the spirit of the eighteenth-century Evangelical Revival to the institutions of twentieth-century mass evangelism. In the middle of the nineteenth century Mousehole and Newlyn stood a little before the midway point of the process while Penzance was located some way after it. The fishing villages were closer to John Wesley and the town to Billy Graham.

\footnotetext{
${ }^{1}$ Salome Hocking, Some Old Cornish Folk [1903] (St Austell, 2002), 155, 154. On the book and its context, see Alan M. Kent, Pulp Methodism: The Lives \& Literature of Silas, Joseph and Salome Hocking, Three Cornish Novelists (St Austell, 2002).

${ }^{2}$ Calvin Colton, The History and Character of American Revivals of Religion (London, 1832), 5, quoted by John Kent, Holding the Fort: Studies in Victorian Revivalism (London, 1978), 18.

${ }^{3}$ Kent, Holding the Fort, 30-31.

${ }^{4}$ J. E. Orr, The Second Evangelical Awakening in Britain (London, 1949), suffers from this weakness.

${ }^{5}$ K. S. Jeffrey, When the Lord Walked the Land: The 1858-62 Revival in the North-East of Scotland (Carlisle, 2002). The book contains a valuable survey of the various historical interpretations of revival at pp. 27-37.

${ }^{6}$ David Luker, 'Revivalism in Theory and Practice: The Case of Cornish Methodism', JEH 37 (1986), 619. Cf. D. H. Luker, 'Cornish Methodism, Revivalism and Popular Belief, c. 1780-1870', Oxford DPhil dissertation (1987), spec. chap. 7.

${ }^{7}$ I am pleased to acknowledge a British Academy grant that enabled me to conduct the bulk of the research for this paper. I am also extremely grateful for the help of John Probert, Cedric Appleby and other specialists in Cornish Methodist history, and for the guidance of the staff at the Cornwall Centre, the Cornwall County Record Office, the Courtney Library of the Royal Institution of Cornwall, Truro, and the Morrab Library, Penzance.

${ }^{8}$ Penzance Journal [hereafter: PJ], 22 November 1848, p. 4.

${ }^{9}$ W. Penaluna, comp., An Historical Survey of the County of Cornwall, new edn, 2 vols (Helston, 1848), 2: 46.

${ }^{10}$ The standard histories of Cornwall and Penzance are Philip Payton, Cornwall: A History, 2nd edn (Fowey, 2004), and P. A. S. Pool, The History of the Town and Borough of Penzance (Penzance, 1974).

${ }^{11}$ Penaluna, comp., Cornwall, 2: 151-52.

${ }^{12}$ Pat A. Waller and Glyn Richards, 'Non-conformity in Newlyn', in Veronica Chesher, ed., Newlyn Life, 1870-1914: The Village that inspired the Artists (Penzance, 2003), 103. On Newlyn, see Margaret E. Perry, Newlyn: A Brief History (Newlyn, 1999).

${ }^{13}$ Richard Treffry, Memoirs of Mr. Richard Trewavas, Sen., of Mousehole, Cornwall (London, 1839), 53.
} 
${ }^{14}$ On Mousehole, see Nettie M. Pender, A Short History of Mousehole with Personal Recollections (Mousehole, 1970), and Margaret E. Perry, Mousehole: A Brief History (Newlyn, 1998).

${ }^{15}$ Wesleyan Methodist Magazine [hereafter: WMM], December 1870, 575.

${ }^{16}$ PJ, 7 February 1849, 4. PG, 7 March 1849, [4].

${ }^{17}$ J. C. C. Probert, ed., 1851 Religious Census: West Cornwall and the Isles of Scilly (n.p., n.d.). The percentages are proportionate shares of total attendances. Other percentages are taken from this source. The remainder of the Penzance churchgoers were split between several other chapels including two of different Methodist persuasions.

${ }^{18}$ Cornish Telegraph [hereafter: CT], 5 December 1860, [4].

${ }^{19} P G, 28$ February 1849, [4].

${ }^{20}$ Robert Young, 'Revival of Religion in the Penzance Circuit', WMM, January 1850 [hereafter: 'Y'], 35. This is the source for otherwise unattributed information in this paragraph.

${ }^{21}$ Truro, Cornwall County Record Office, Circuit Schedule Book for Penzance Circuit [hereafter: CSB], 1843-49, MR/PZ/31. The other statistics in this paragraph are from this source.

${ }^{22}$ PJ, 30 August $1848,4$.

${ }^{23} P G, 13$ December 1848, [4].

${ }^{24} P J, 21$ February $1849,4$.

${ }^{25} \mathrm{Y}, 39$.

${ }^{26}$ John Hobson, 'Revival of Religion in the Penzance Circuit', WMM, May 1832, 365.

${ }^{27}$ Pool, Penzance, 121-22. PG, 15 November 1848, [3].

${ }^{28}$ PJ, 16 August $1848,3$.

${ }^{29}$ PJ, 16 August 1848, 3; 23 August 1848, 3; 20 September 1848, 3; 4 October 1848, 3.

${ }^{30} P G, 18$ October 1848, [4]; 29 November 1848, [4].

${ }^{31} P J, 25$ October 1848, 4.

${ }^{32}$ PJ, 20 September 1848, 3; 27 September 1848, 4.

${ }^{33} P G$, 3 January 1849, [3]. West Briton [hereafter WB], 19 January 1849, [3]. PG, 17 January 1849, [3].

${ }^{34} P G, 18$ October $1848,[4]$

${ }^{35} \mathrm{Y}, 39$.

${ }^{36}$ Robert Hunt, Popular Romances of the West of England, 2nd series (London, 1865), 146.

${ }^{37} P G, 11$ October $1848,[4]$.

${ }^{38} P J, 20$ December $1848,4$.

${ }^{39}$ PJ, 20 December 1848, 4. PG, 20 December 1848, [4].

${ }^{40} P G, 27$ December 1848, [4].

${ }^{41}$ J. H. Rigg, Wesleyan Methodist Reminiscences : Sixty Years Ago (London, 1904), 72. Pool, Penzance, 139.

${ }^{42}$ Richard Carwardine, Transatlantic Revivalism: Popular Evangelicalism in Britain and America, 1790-1865 (Westport, CT, 1978), 56.

${ }^{43}$ John Riles, An Account of the Revival of the Work of God in the County of Cornwall (Penryn, 1814), 8, 20. M. S. Edwards, 'Cornish Methodism: A Study in Division, 1814-1857', Birmingham MA dissertation (1962), 23.

${ }^{44}$ Hobson, 'Revival', 361-65. CSB, 1837-43, MR/PZ/30; 1843-49.

${ }^{45}$ Hobson, 'Revival', 362.

${ }^{46}$ Robert Young, Showers of Blessing: Or Sketches of Revivals of Religion in the Wesleyan Methodist Connexion: With Observations Thereon (London, 1844), 229-49.

${ }^{47}$ Robert Young, 'A Missionary Sermon', Cornish Banner [hereafter: CB] (1846-47), 14.

${ }^{48} P G, 4$ April 1849, [4].

${ }^{49}$ Treffry, Trewavas, 158-62.

${ }^{50} \mathrm{CSB}, 1843-49,27$.

${ }^{51}$ The Report of the Wesleyan-Methodist Missionary Society (London, n.d.), xv, for successive years.

${ }^{52}$ Elaine Horner, Samuel Symons: Missionary to the Gambia, 1842-44 (n.p., n.d.).

${ }^{53} C T, 17$ June $1903,2$.

${ }^{54}$ PJ, 6 December 1848, 4. Y, 35, where one of the society stewards was Rowe, probably the one with three children converted.

${ }^{55}$ Wesley Banner, April 1849, 56.

${ }^{56} \mathrm{Y}, 38$.

${ }^{57}$ G. P. Despard, Hope Deferred, not Lost: A Narrative of Missionary Effort in South America in connection with the Patagonian Missionary Society (London, [1852]), 136. Phyllis Thompson, An Unquenchable Flame (London, 1983). 
${ }^{58}$ Benjamin Gregory, Side Lights on the Conflicts of Methodism (London, 1899), 246.

${ }^{59}$ William Dale to Jabez Bunting, 12 July 1839 and 15 July 1842, in W. R. Ward, ed., Early Victorian Methodism: The Correspondence of Jabez Bunting, 1830-1859 (Oxford, 1976), 225-29, 273-76.

${ }^{60}$ George Smith, History of Wesleyan Methodism, 2 vols (London, 1858), 2: 604.

${ }^{61}$ Rigg, Reminiscences, 54-55.

${ }^{62}$ Ward, ed., Early Victorian Methodism, 229n. WB, 1 October 1891, 3. London, National Archives, Returns for the 1851 Census for Cornwall, HO 107/1918 [hereafter 1851 Census], fol. 693.

${ }^{63} \mathrm{WB}, 8$ October 1891, supplement, p. 2.

${ }^{64}$ Robert Young, Suggestions for the Conversion of the World, respectfully submitted to the Christian Church (London, 1841), 49.

${ }^{65}$ Rigg, Reminiscences, 68. Robert Young, The Serious Inquirer after Salvation affectionately addressed, 2nd edn (London, 1838), 8. CT, 29 August 1851, [2].

${ }^{66}$ Young, Showers of Blessing, 456, 273-74.

${ }^{67}$ WMM, September 1866, 847.

${ }^{68}$ London, University of London, School of Oriental and African Studies, Wesleyan Methodist

Missionary Society Home and General Minutes, FBN 7, 22 November 1843, 27 March 1844. Robert

Young, The Southern World: Journal of a Deputation from the Wesleyan Conference to Australia and Polynesia (London,1854).

${ }^{69}$ CT, 11 July $1851,[2]$.

${ }^{70}$ Young, Suggestions, 71-73, 92, 98.

${ }^{71} P J, 20$ September $1848,4$.

${ }^{72}$ Truro, Cornwall County Record Office, Penzance Wesleyan Methodist Local Preachers' Minute

Book, 1845-63, MR/PZ/12, 26 September 1848, 32.

${ }^{73} \mathrm{Y}, 34$.

${ }^{74}$ Robert Young, 'Recent Revival of Religion at Truro', WMM, June 1847, 610.

${ }^{75}$ Hobson, 'Revival', 362, 365.

${ }^{76}$ Young, 'Truro', 611.

${ }^{77}$ Young, Showers of Blessing, 423-28, at 451.

${ }^{78}$ Young. 'Truro', 610.

${ }^{79}$ Young, Showers of Blessing, 447, 458.

${ }^{80} \mathrm{Y}, 34-35,36-37$, at 34.

${ }^{81}$ WMM, November 1849, 1213 (Maria Akerman).

${ }^{82}$ B [enjamin] Carvosso, ed., The Efficacy of Faith in the Atonement of Christ: exemplified in a Memoir of Mr. William Carvosso, Sixty Years a Class-Leader in the Wesleyan-Methodist Connexion (London, n. d.), 92.

${ }^{83} \mathrm{Y}, 37$.

${ }^{84} \mathrm{Y}, 38$.

${ }^{85}$ Young, 'Truro', 611. Young, Showers of Blessing, 450-51.

${ }^{86}$ G. C. Boase, Collectanea Cornubiensia (Truro, 1890), col. 543. Y, p. 35, noting that five children of a circuit steward were converted. Matthews was the circuit steward with five children between the ages of fourteen and twenty-three. 1851 Census, fol. 741.

${ }^{87}$ CSB, $1843-49$.

${ }^{88}$ G. C. Boase, Reminiscences of Penzance, ed. P. A. S. Pool (Penzance, 1976), 24-27. WMM,

December 1849, 1318. During the revival Barnes's nineteen-year-old assistant at Regent House, Caleb Shipman, started a boys' class of converts, and shortly afterwards George Bettany, the master at the Wesleyan day school in the town, joined him as a class leader.

${ }^{89} \mathrm{CSB}, 1849-64, \mathrm{MR} / \mathrm{PZ} / 32.1851$ Census, fol. 525. Boase, Reminiscences, 28.

${ }^{90} \mathrm{CSB}, 1849-64 ; 1864-77$, MR/PZ/33. 1851 Census, fol. 736.

${ }^{91}$ John Corin, Fishermen's Conflict: The Story of a Cornish Fishing Port (Newton Abbot, 1988), 27.

${ }^{92} C T, 28$ November 1860, [4].

${ }^{93}$ Charles Thomas, The Taboo in Cornwall (n.p., 1951), 25. Pender, Mousehole, 38.

${ }^{94}$ William Bottrell, Traditions and Hearthside Stories of West Cornwall, 2nd series (Penzance, 1873), 245, 246; 3rd series (Penzance, 1880), 156.

${ }^{95}$ Percy Harvey, 'Mousehole alias Porthennis: The Chronicle of a Seafaring Community' (TS, 1994), 110.

${ }^{96}$ Harvey, 'Mousehole', 145. Wesleyan Education Committee Report, 20 (1859), 42.

${ }^{97}$ William Bottrell, Traditions and Hearthside Stories of West Cornwall (Penzance, 1870), 179.

${ }^{98}$ Pender, Mousehole, 38. 
${ }^{99}$ D. W. Bebbington, 'Holiness in Nineteenth-Century British Methodism', in W. M. Jacob and Nigel Yates, eds, Crown and Mitre: Religion and Society in Northern Europe since the Reformation (Woodbridge, Suffolk, 1993), 161-74.

${ }^{100}$ Carvosso, ed., Carvosso, 84. John Hobson, 'New Chapels opened in the Penzance Circuit', WMM, July $1833,523$.

${ }^{101}$ Young, Suggestions, 79, 51.

${ }^{102}$ Treffry, Trewavas, 68. Carvosso, ed., Carvosso, 15-16, 286.

${ }^{103}$ WMM, June $1824,425$.

${ }^{104}$ WMM, December 1870, 575.

${ }^{105}$ A[delaide] W. Y[oung], 'Reminiscences: A Fisher of Men', Cornish Methodist Church Record [hereafter: $C M C R$ ], March 1893, cutting in Truro, The Royal Institution of Cornwall, The Courtney Library, Thomas Shaw Collection, Mousehole section.

${ }^{106}$ W. S. Lach-Szyrma, A Short History of Penzance, S. Michael's Mount, S. Ives, and the Land's End District (Truro, 1878), 185.

${ }^{107} \mathrm{Y}, 37,35$.

${ }^{108}$ Y [oung], 'Reminiscences'.

${ }^{109}$ Young, Showers of Blessing, 441, 435.

${ }^{110}$ Delta [Robert Young], 'Revivals of Religion - No. II', CB (1846-47), 219. Most of the account of revivals published in this periodical that Young edited while at Truro is extracted from Showers of Blessing, but there are occasional alterations, of which this is one.

${ }^{111} P J$, 31 January 1849,4 . This source gives the victim's age as 59 ; the source in the next note gives it as about 63 .

${ }^{112} P G, 31$ January $1849,[4]$

${ }^{113} \mathrm{Y}, 37$

${ }^{114}$ J. J. Beckerlegge, Two Hundred Years of Methodism in Mousehole (Mousehole, 1954), 24.

${ }^{115} \mathrm{Y}, \mathrm{p}$. 37. The prominence of women in cottage prayer meetings is brought out by Deborah Valenze, Prophetic Sons and Daughters: Female Preaching and Popular Religion in Industrial England (Princeton, NJ, 1985).

${ }^{116} \mathrm{Y}, 35-37$

${ }^{117} 1851$ Census, fol. 199. Young, 'Reminiscences'.

${ }^{118} \mathrm{CSB}, 1843-49$; 1849-64. Information about new admissions in this paragraph is taken from these volumes.

1191851 Census, fol. 223.

${ }^{120}$ John Ash, William Harry and Thomas Matthews: 1851 Census, fols 225, 224.

${ }^{121}$ Respectively Abraham Chirgwin, Susan Tonkin; Nicholas Berriman (though his shop was in Penzance), Benjamin Dale, George Richards; William Wallis; ? Hosking, ? Smith (both unidentifiable in census); and Richard Richards. 1851 Census, fols 309, 267; 624, 306, 236; 283; 277.

${ }^{122} \mathrm{Y}, 36$.

${ }^{123}$ CSB, $1843-49,26$.

${ }^{124}$ The process was national. Robert Currie et al., Churches and Churchooers: Patterns of Church Growth in the British Isles since 1700 (Oxford, 1977), 71.

${ }^{125}$ Levi Woolley of Mousehole and John Champion of Newlyn. CSB, 1849-64.

${ }^{126}$ CMCR, April 1893; and 1895, Shaw Collection, Mousehole section. 